\title{
Sergey Sergeevich Korsakov (1854-1900)
}

\author{
Alla Vein
}

Received: 8 July 2009/Revised: 14 July 2009/Accepted: 4 August 2009/Published online: 19 August 2009

(C) The Author(s) 2009. This article is published with open access at Springerlink.com

Sergey Sergeevich Korsakov was the first Professor of Psychiatry in Russia and founder of the Moscow school of psychiatry (Fig. 1). Although he was head of the psychiatric clinic of Moscow University for only 12 years, his clinical approach and organizing skills influenced the direction in which Russian psychiatry developed and put it on the international map.

Korsakov was born in 1854 in a large village in central Russia. On finishing school-the Moscow gymnasium-at the age of 16, he enrolled in the medical faculty of Moscow University. By 1875 he was a physician at the Moscow Preobrazhenskij mental hospital and 1 year later he joined the department of nervous and mental diseases, headed by Aleksey Yakovlevich Kozhevnikov (1836-1902). Korsakov became his closest and most talented pupil.

During his professional career, Korsakov frequently travelled abroad in order to familiarize himself with the psychiatric service in Europe. His first trip was in 1885 to Vienna, where he visited Theodor Meynert. In 1889 he went to Germany, Switzerland, France and Italy. He visited Westphal in the Berlin Charité, Flechsig in Leipzig, and Magnan in Paris. In 1892 he paid a visit to Krafft-Ebing in Vienna and in 1894 to Kraepelin in Heidelberg. These visits helped Korsakov to establish close contacts with leading European neurologists and psychiatrists.

His thesis "About alcoholic paralysis" gained him his medical doctorate in 1887. In the same year, the first Clinic for Nervous and Mental Diseases was founded in Moscow University, with Kozhevnikov at its head. Working closely with Kozhevnikov, as assistant professor,

\footnotetext{
A. Vein $(\bowtie)$

Leiden University Medical Center,

Leiden, The Netherlands

e-mail: a.a.vein@lumc.nl
}

Korsakov was in charge of theoretical and practical training in psychiatry; he gave his first lecture in autumn 1888. For Korsakov, and for Russian psychiatry, the subsequent years were a time of great development and diverse activity. Kozhevnikov considered, however, that clinical neurology as an independent specialty should be separated, not only from internal medicine, but also from psychiatry [1]. He was, therefore, simultaneously building a second, new Clinic for nervous diseases. With the permission of the Moscow University Medical faculty, he transferred the control over the first clinic to Korsakov, one of his best pupils, and in 1890 it became exclusively a clinic for psychiatric patients. This was a historical moment of separation between neurological and psychiatric disciplines in Moscow, whereas elsewhere in Europe and even in Russia, e.g. St. Petersburg, the two disciplines would continue to be practised together for a long time [2].

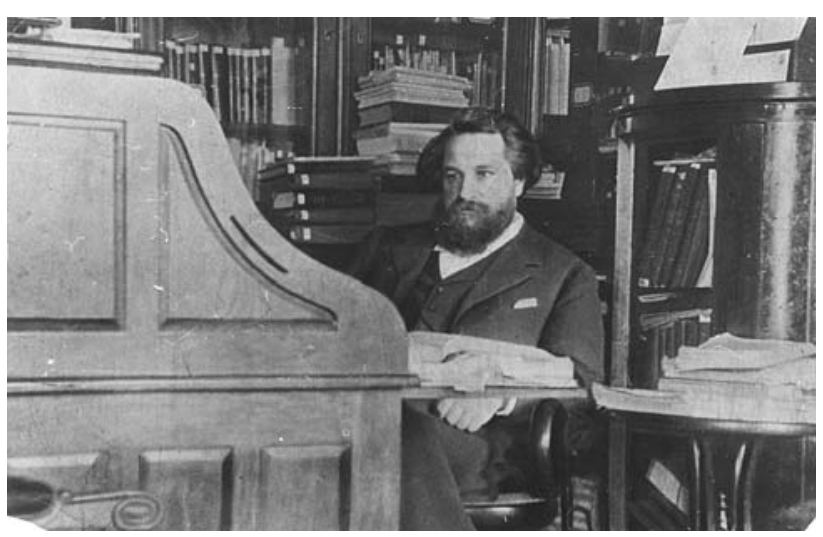

Fig. 1 S.S. Korsakov (1854-1900). Photo from Historical Museum of Moscow Medical Academy (with permission) 
Korsakov actively participated in promoting the rights of the mentally ill. In fact, he headed both the Moscow University Psychiatric Clinic and a private institution, the oldest private clinic for the mentally ill in Moscow, founded in 1830. The regimen in the clinic was more flexible and more humane than in public asylums. Korsakov went further than anyone else in avoiding restraints, removing bars and abolishing straight-jackets and isolation cells [3]. Korsakov promoted a humane approach to the mentally ill not only in Russia, but also internationally. He was a strong opponent of forced sterilization of the mentally ill, something that was happening in the US. This is the reason why some historians of medicine call Korsakov "the Russian Pinel". Thanks to his energy and enthusiasm, this norestraint approach to the care of the mentally ill was implemented in Russia rather quickly [4].

As chief of the Moscow University Psychiatric Clinic, Korsakov defined the nosological approach in the study of psychoses. He applied his ideas in practice while studying the clinical features of alcoholic polyneuritis with distinctive mental symptoms-'cerebropathia psychica toxaemica'. In 1889, Korsakov published his work "Several cases of a particular cerebropathia and polyneuritis". This disorder is characterized by polyneuritis with a variable degree of limb muscle atrophy as well as disturbed memory, with amnesia, confabulations and pseudoreminiscences. He published other works on this topic, further developing the theory of polyneuritic psychosis [5, 6]. Korsakov presented a report "On a special form of mental illness combined with degenerative polyneuritis" at the XII International Medical Congress in Moscow in 1897. He was a member of the organizing committee of the congress, which was attended by many prominent European neurologists and psychiatrists. Many of them visited the Clinic for Nervous and Mental Diseases, and all 45 foreign colleagues became members of Moscow Society of Neurology and Psychiatry. It was during this congress that the eponym 'Korsakov's disease' was coined by Jolly $[7,8]$.

Apart from the studies on alcoholic psychosis, Korsakov introduced the concept of paranoia. Consequently, paranoia (acute and chronic), hallucinatory madness (acute) and primary, curable weak-mindedness were outlined. He presented the concept of 'dysnoia', which might be considered a precursor of acute schizophrenia. Korsakov was the first to note the specific signs of the 'basic disorder' of this illness and formulated his theory of 'dysnoia' in 1891 before Kraepelin's description of dementia praecox.

In line with the main direction of Korsakov's clinical view, his classification of the psychiatric disorders became the most significant achievement in Russian psychiatry at the turn of the nineteenth into the twentieth century [4].

Korsakov was also a founder of the field of forensic psychiatry in Russia. He conducted the most difficult evaluations either himself or together with his collaborators and published case series on this subject including evaluations of the most important and well-known judicial trials of his time.

Korsakov wrote a Course of Psychiatry published only a year after his death. After two heart attacks at the age of 44, he consulted a specialist in Vienna in 1898 who established the diagnosis hypertrophy of the heart, associated with obesity and myocarditis. He died in 1900 from heart failure, at the age of 46. In 1901 his teacher, Kozhevnikov founded a leading Russian journal of neurology and psychiatry and named it after Korsakov: Zhurnal nevropatologii i psikhiatrii imeni S. S. Korsakova.

The Moscow Psychiatric Clinic bears his name. A monument to his memory was erected in front of the clinic, the plaque reading: "To S. S. Korsakov—scientist, psychiatrist, thinker, humanist" [9].

Open Access This article is distributed under the terms of the Creative Commons Attribution Noncommercial License which permits any noncommercial use, distribution, and reproduction in any medium, provided the original author(s) and source are credited.

\section{References}

1. Grashchenkov NI (1960) Relationships between British and Russian medicine and neurology, and the role of the National Hospital, Queen Square, London in the development of Russian neuropathology. J Neurol Neurosurg Psychiatry 23:185-190

2. Vein AA (2007) The Moscow clinic for nervous diseases. Walking along the portraits. J Hist Neurosci 16:42-57

3. Sirotkina I (2002) Diagnosing literary genius: a cultural history of psychiatry in Russia, 1880-1930. The Johns Hopkins University Press, Baltimore, p 269

4. Ovsyannikov SA, Ovsyannikov AS (2007) Sergey S. Korsakov and the beginning of Russian psychiatry. J Hist Neurosci 16:58-65

5. Korsakoff SS (1890) Eine psychische Störung combinirt mit multipler Neuritis (Psychosis polyneuritica seu Cerebropathia psychica toxaemica). Allgem Zschr Psychiatr 46:475-485

6. Korsakoff SS (1890) Ueber eine besondere Form psychischer Störung, combinirt mit multipler Neuritis. Arch Psychiatry 21:669-704

7. Kannabikh YuV (1929) Istoria psikhiatrii (History of Psychiatry). Medgiz, Leningrad, 520 pp (Russ.)

8. Lisitsin YuP (1961) Kozhevnikov AYa i moskovskaya shkola nevropatologov [Kozhevnikov AYa and Moscow neurological school]. Medgiz, Moskva, 257 pp (Russ.)

9. Chodos HBG (1965) Kratkij ocherk otechestvennoj nevrologii. Irkutsk.Vostochno Sibirskoe Knignoe Izdateljstvo, 62 pp. (Russ.) 